\title{
CONTEMPORARY CLIMATE CHANGES AS A FACTOR FOR CENTRAL RUSSIAN FOREST-STEPPE LANDSCAPE DEVELOPMENT (IN THE KURSK REGION TAKEN AS AN EXAMPLE)
}

DOI: http://dx.doi.org/10.18509/GBP.2019.18

UDC: $551.583: 911.52 \mid(470)$

\author{
Olga Pavlovna Lukashova \\ Margarita Alekseevna Bogatyreva \\ Elena Sergeevna Dmitrova \\ Irina Yuryevna Soshnikova \\ Kursk State University, Russia
}

\begin{abstract}
The main common factors of space-time allocation of the main meteorological parameters and estimate climate indicators characterizing hydrothermal regime at the territory of the Kursk Region have been reviewed in the investigation. The maps of climatic territory zoning in the Region have been worked out basing on dynamics of climatic characteristics indicators. The investigation methods have had a complex character: analysis of scientific and reference books, examination and estimation of climatic parameters in the field conditions: cartographic, mathematic and statistic methods have been used to process and present the obtained materials.
\end{abstract}

Key words: climate, hydrothermal regime, climatic zoning

\section{INTRODUCTION}

The estimation of contemporary climatic changes and the forecast of prospective ones are one of the top problems in the Earth sciences. The processes having been viewed recently are seen both in the global and regional levels. Dynamics of such climatic parameters as temperature regime and rainfall regime determines the conditions for landscape changes. Dynamics of hydrothermal parameters is of special interest. Study of space-time peculiarities of air temperature and rainfall changes have a great importance for working out regional scenarios for future climatic changes and for decision of a range of practical tasks connected with efficient use of agroclimatic resources.

Meteorological examination at the territory of the Kursk Region is held at the territory of all the landscape regions. However, in spite of the fact that the climate and landscapes in the Kursk Region have been studied and described quite well in the works on landscape science but climatic characteristics obtained half century ago are still used. In the last years the investigations on landscape climate have been held but there haven't been held such investigations in the Kursk Region.

Contemporary climate changes in the forest-steppe zone don't cause a great transformation of landscape structure of the territory. It determines forest-steppe landscape stability to contemporary changes. So the estimation of climate changes influence on landscape structure of the Region is considered to be urgent and is of both theoretical and practical interest. 


\section{THE REGION FOR INVESTIGATION, OBJECTS AND METHODS}

Statistic data on climate changes in forest-steppe landscape of the Kursk Region in the period of 1950-2016 taken from the fund of the Central Black-Soil Weather Control and Environmental Monitoring Service have formed the base of the investigation. During the investigation the following methods have been used: field study method, the investigations have been held in the key territories of the Kursk Biosphere Station of the Institute of Geography of the Russian Academy of Science: method of mathematic modelling and statistic processing including the amount of approaches of numeric data processing. Mathematic and statistic processing of the data has been held by means of the statistical analysis package MSExel; method of distance testing (aerospace method) gives a complex understanding of landscape structure and allows to follow the change of biosphere components.

\section{RESULTS OF THE INVESTIGATION}

The Kursk Region is located in the middle latitudes of the variable zone in the center of East European Plain, at the south-western slopes of Central Russian Upland, at the foreststeppe zone. The Region has always had comfortable environment for both forest and steppe vegetation. Nowadays the most of the Region is plowed up and occupied with agricultural crops. Forest-steppe systems depend both on natural climatic and meteorological conditions and on longtime anthropogenic influence. Nowadays we can speak about forest-steppe landscape as about past one as it has been preserved in unchangeable state at the territory less than $1 \%$ of the whole Region (nature reserve, natural monuments). In1935 Central Black Earth Nature Reserve named after V.V. Alekhin was founded in the Kursk Region. Nowadays it is presented by six separate territories: Streletsky, Kazatsky, Bukreevy Barmy, Barkalovka, Zorinsky, the Psel overflow land, and it occupies the territory more than 5,000 ha. The Nature Reserve is the example of forest-steppe landscapes. In a whole in the Region there is a complicated mosaic of landscape foundations: territories never touched by a man (nature reserves); territories slightly changed by a man still able to restore its initial structure (forests of natural and anthropogenic origin, reserves, grazing lands, earth boards with newly formed ecosystem); territories irreversibly changed by a man (carriers and reserves, agricultural lands, lands highly affected by erosion, inhabited lands and others) [5].

According to the peculiarities of the main climatic features (temperature, air humidity, rainfall), the climate of the Kursk Region is moderate continental, which main differences are a great annual temperature amplitude; relatively long moderate cold winter with stable snow covering and snowstorms; sunny warm, sometimes hot and dry, summer; prevalence of summer rainfall over winter one [1] .

Modern condition of forest-steppe landscape is characterized by periodical oakery death which is resulted from sharp climate factors declinations in comparison with average data of many years. According to the data got by Federal State Budget Institution «Central Black Soil Zone Administration on Hydrometeorology and Environment Monitoring (AHEM)», such dangerous hydrometeorologic events as soil and air droughts have been observed several times at the most part of the Region in the third decade of July - the first decade of August. Later extremely low temperatures in winter cause a great weakness of trees [2].

While studying climate changes the main interest has been given to two main elements: temperature regime and moisturization. To analyze the parameters of climate changes, 
the meteorological stations of the Kursk Region located in the north (Ponyri); in the east (Tim); in the south (Oboyan); in the west (Rylsk) and in the regional center (Kursk) have been chosen.

Air temperature is one of the most important climatic elements. The main features of temperature regime are annual and monthly average air temperatures. According to the data got by Federal State Budget Institution «Central Black Soil Zone Administration on Hydrometeorology and Environment Monitoring (AHEM)», for the last few years the annual and monthly average temperatures have increased. Annual average air temperatures have increased at all the stations $0,6-0,8^{\circ} \mathrm{C}$ since the middle of the $20^{\text {th }}$ century. The average air temperature of many years in winter months for the last decades has increased the norm of many years. Winter months have become warmer for $1-1,5^{\circ} \mathrm{C}$. So in the Kursk Region there is a tendency of annual average temperature growth, especially due to winter months [7].

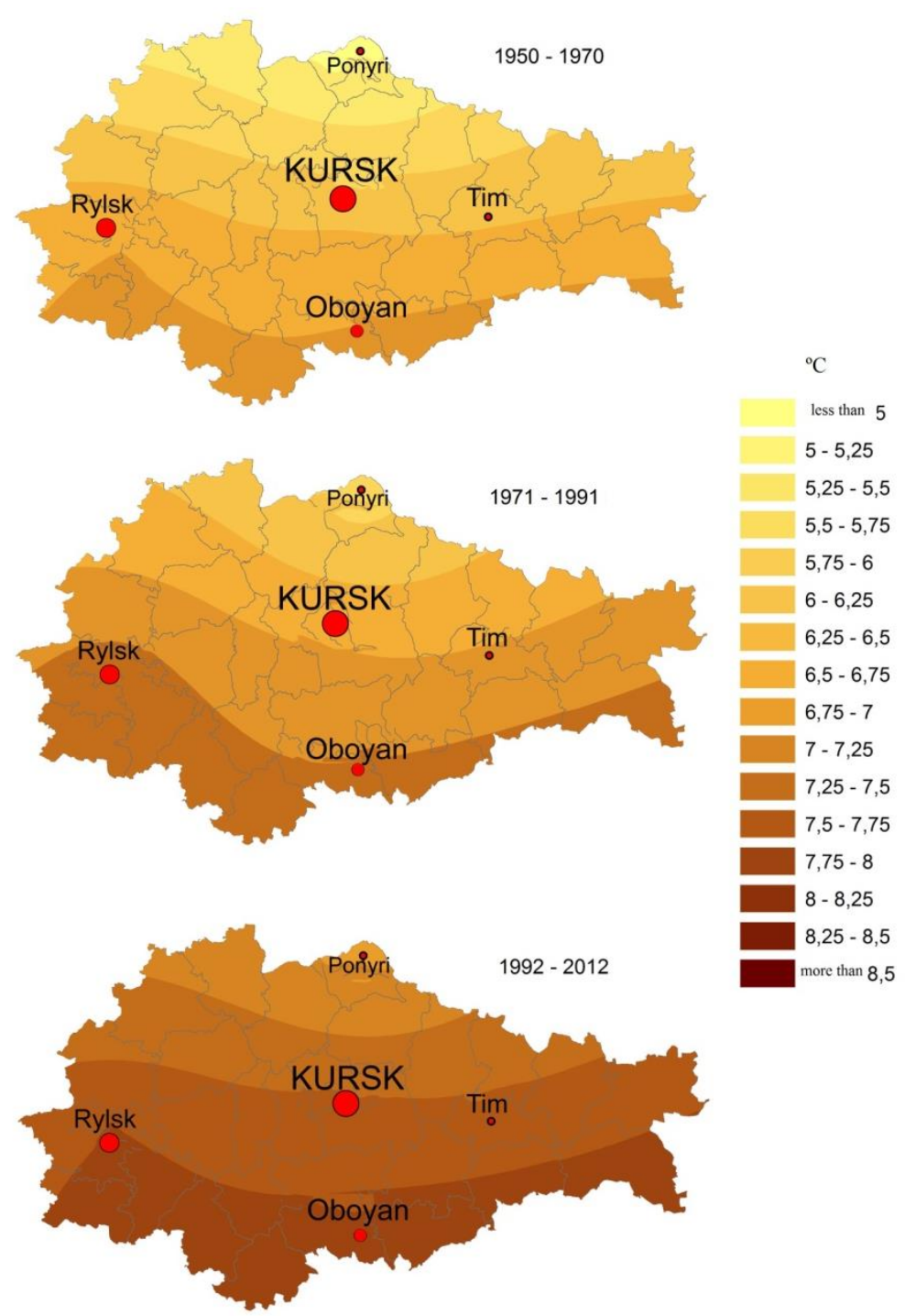

Figure 1. Change of annual average temperature

Having analyzed the annual average indicators of temperature regime in the Kursk Region, it has been reviewed that these indicators are much higher than those of many 
years. The average air temperatures of many years have greatly changed in winter periods. The tendency of annual average temperatures change for the studied period has been positive at the whole territory of the Region. The biggest growth is observed since the 1990s [7] (Figure 1).

In the dynamics of change in annual and seasonal amount of rainfall in the Kursk Region in the period of 1950-2015, the following peculiarities are seen. At the most part of the Region during the studied period the tendency of rainfall change has been positive. In the Region the west is mostly moistened and the east is less moistened [7] (Figure 2).
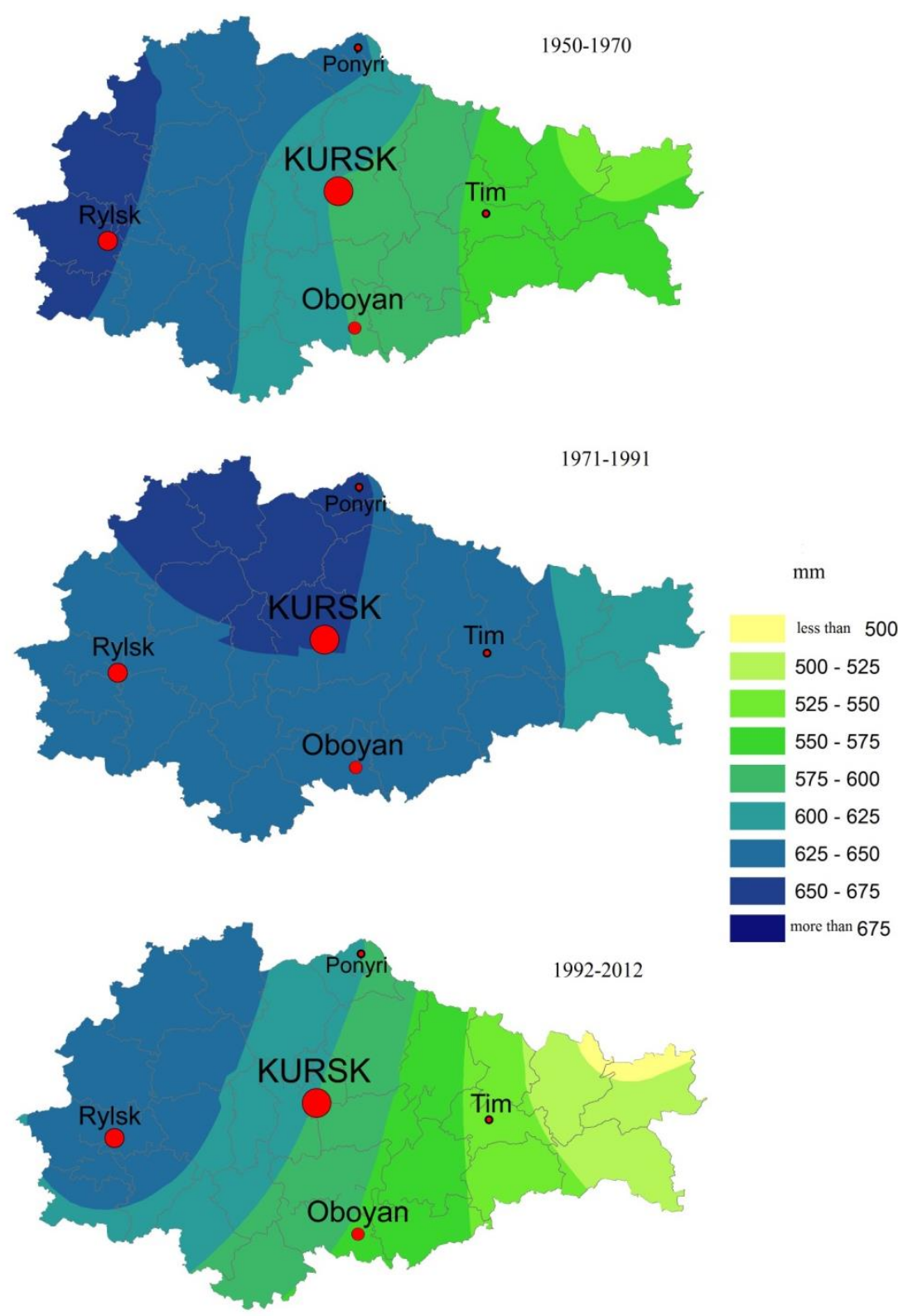

Figure 2. Change of annual average rainfall

Having analyzed the dynamics of rainfall changes in forest-steppe landscape in the Kursk Region for the period since 1950 till nowadays, different tendencies in dynamics of seasonal indicators are reviewed. Thus, the main increase of winter rainfall happened in 1965-1970. The amount of rainfall in winter period for the last decade was not stable; it 
is proved by the cyclism of snow covering power, its density and water content. According to the examinations the last decade was not characterized by sharp change in snow covering in spite of periodicity of warm and cold winters. The amount of winters with low content of snow has mostly increased [3].

A great contribution in the amount of rainfall is caused by the rainfall fallen during warm period. An important peculiarity of the changed moisturization has become the increase of rainfall probability. The number of the days with heavy rains has increased [4].

Such dangerous events as droughts and dry hot winds have been registered several times at the territory of the Region. According to «The data of dangerous natural hydro meteorological events registered об at the territory governed by Federal State Budget Institution «Central Black Soil Zone Administration on Hydrometeorology and Environment Monitoring (AHEM)», similar events were observed at the most part of the Region in the third decade of July - the first decade of August. It means that the period of 2-3 decade droughts has been increasing by the beginning of the $21^{\text {st }}$ century, which may negatively affect vegetation and cause accidental soil and air droughts. Besides, during the period under study the increase of the number of hot days has been observed since 1996. Fire danger was registered at the territory of more than $70 \%$ in the beginning of 2000s and in 2010 and 2015 [6]



Figure 3. Number of hot days

At the same time the number of days with heavy rainfall has also increased. Probably the increase of annual rainfall is explained by forcing latitude circulation and spreading hot humid air from the Atlantic Ocean and the Mediterranean sea to the Region.

Negative aftermaths of climate changes may cause the increase of repetition of dangerous hydro meteorological events. Forecasting geoecological aftermaths after regional climate changes (the Kursk Region taken as an example) lets us estimate their economic effect. We will study possible landscape and climate changes due to increase annual air temperature for $1{ }^{\circ} \mathrm{C}$ in the next 10 years and due to annual rainfall for $30 \mathrm{~mm}$ in comparison with contemporary data using comparative geographical method.

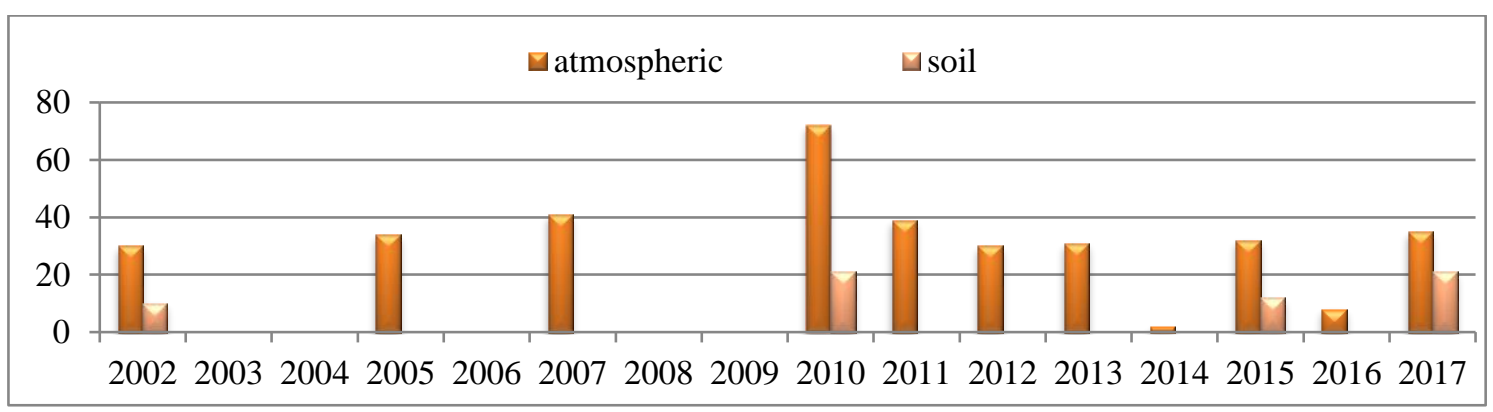

Figure 4. Number of days with drought 
Forest and meadow phytomass will increase and the indicators of soil covering (content of humus, nitrogen and phosphorus) bear opposite changes. Moderate decrease of these data is probably connected with increase of their assimilation with growing phytomass of forest and meadow vegetation and also with increase of cowering yield and seepage. Similar situation will be found in agricultural landscape. But decrease of substance content in soil will also be connected with increase its yield with harvest. The tendency of nitrogen and phosphorus content increase in surface water will be observed. It is explained by increase of getting these substances with surface flow and seepage.



Figure 5. The amount of rainfall (mm) fallen in the form of heavy rain

Geoecological aftermaths of climate changes can't be estimated absolutely. It is possible to estimate changes of the following parameters as positive. The productivity and phytomass of forest and meadow vegetation covering is increasing. It will probably happen by means of increase of the amount of broadleaved woodland and meadow plants that will make geobotanic diversity and will increase functions forming environment and those forming resources of forest and meadow geosystems.

In the Kursk Region agroclimatic resources play the most important role as agricultural industry takes key sectors in the economics of the Region.

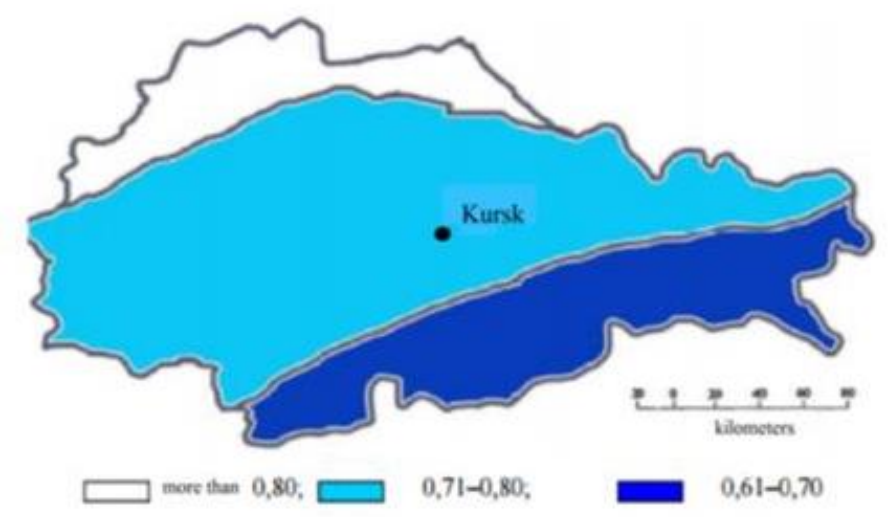

Figure 6. The Kursk Region's zones with unordinary natural water availability

Nowadays in the agroclimatic investigations a new direction has appeared: agroclimatic resources are estimated as climate possibilities which any territory has to get agricultural goods. The form of presenting agroclimatic resources is the data on crops productivity depending on climate peculiarities of the territory. 
To estimate agroclimatic resources it is important to understand the level of water availability or water shortage at the territory. We have studied these conditions basing on hydrothermal coefficient. It (Selyaninov's hydrothermal humidity factor) is widely used to make a general estimation of climate and to settle the zones with different humidity in order to determine advantages of growing these or those crops.

According to Selyaninov, the northern border of the steppe zone is defined by isoline K $=1$. The territory of the Kursk Region is situated close to this line, and thus, is affected by the aftermaths of even slight change in this indicator.

Zoning of the territory of the Kursk Region held before basing on natural water availability [Smolyaninov, Starodubtsev 2011] has allowed to make three zones with different coefficients of natural water availability of the lands (Fig.6)

Hydrothermal factor at the territory under investigation is changing greatly. The north and north-west of the Kursk Region are considered to be a perhumid zone ( $\Gamma \mathrm{TK}>1,5)$, the central part is moderate humid zone $(\Gamma T K=1,1-1,5)$, the south and south-east are unstable humid zone $(\Gamma \mathrm{TK}=0,9-1,1)$.

The analysis of the data determining the rate of hydrothermal factor (Table 1) has allowed to determine that the value of the coefficient in a whole is rather stable in spite of the changes in sum of active temperatures and amount of rainfall during the vegetative period.

Table 1. Hydrothermal factor and its determinants in the period of $2007-2016$ at the station Kursk

\begin{tabular}{|c|c|c|c|c|c|c|c|c|c|c|}
\hline \multirow[b]{2}{*}{ Year } & \multirow[b]{2}{*}{ 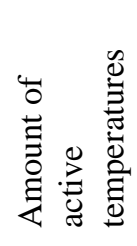 } & \multirow[b]{2}{*}{ 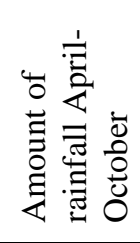 } & \multicolumn{7}{|c|}{ Hydrothermal factor } & \multirow[b]{2}{*}{ 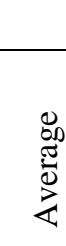 } \\
\hline & & & $\bar{z}$ & $\vec{\Xi}$ & $\stackrel{\Xi}{\Xi}$ & $\stackrel{\gtrsim}{\Xi}$ & $\begin{array}{l}\overline{\tilde{D}} \\
\overrightarrow{00} \\
\vec{Z}\end{array}$ & $\begin{array}{l}\overline{0} \\
\text { है } \\
\text { चू } \\
\text { Dे }\end{array}$ & $\begin{array}{l}\dot{\bar{d}} \\
\stackrel{0}{0} \\
\stackrel{0}{0}\end{array}$ & \\
\hline 2007 & $3136^{\circ} \mathrm{C}$ & 340 & 0,5 & 0,6 & 0,8 & 2 & 0,9 & 0,4 & 0,4 & 0,8 \\
\hline 2008 & $3167^{\circ} \mathrm{C}$ & 378 & 0,9 & 4,0 & 1,3 & 0,9 & 1,5 & 0,7 & 0,6 & 1,6 \\
\hline 2009 & $3143^{\circ} \mathrm{C}$ & 411 & 0,6 & 1,0 & 1,5 & 1,2 & 1,8 & 0,5 & 1,2 & 1,1 \\
\hline 2010 & $3636^{\circ} \mathrm{C}$ & 134 & 0,5 & 1,2 & 0,6 & 0,7 & 0,6 & 1.0 & 2,4 & 0,9 \\
\hline 2011 & $3052^{\circ} \mathrm{C}$ & 320 & 0,5 & 1,3 & 0,8 & 1,2 & 0,9 & 0,7 & 1,4 & 1 \\
\hline 2012 & $3402^{\circ} \mathrm{C}$ & 342 & 0,7 & 0,8 & 0,9 & 1,2 & 0,9 & 1,8 & 0,9 & 1 \\
\hline 2013 & $3116^{\circ} \mathrm{C}$ & 378 & 0,9 & 0,6 & 1,2 & 1,2 & 1,6 & 1,0 & 1,4 & 1,1 \\
\hline 2014 & $3432^{\circ} \mathrm{C}$ & 328 & 0,5 & 0,6 & 0,8 & 1,1 & 1,8 & 1,1 & 1,5 & 1 \\
\hline 2015 & $3254^{\circ} \mathrm{C}$ & 360 & 0,7 & 0,6 & 1,0 & 1,2 & 0,9 & 1,2 & 1,4 & 1 \\
\hline 2016 & $2981^{\circ} \mathrm{C}$ & 428 & 0,6 & 0,9 & 1,8 & 1,2 & 1,9 & 2,7 & 2,6 & 1,6 \\
\hline
\end{tabular}

Minimal values of hydrothermal factor coincide with the period of minimal amount of rainfall and maximal temperatures. In June-August hydrothermal factor was minimal in the period of 2008-2010. Maximal hydrothermal factor of this period was in 2009 and 2013-2016. Humidity shortage in June-August 2010 was maximal for the last ten years. The values were higher than average ones in 2008 and 2016. The comparison with background values shows that during the period under the investigation in the central part of the Region the values decreased from moderate humid zone to unstable humid one.

Thus, separate data om climate resources (temperature) have a tendency to growing but some of them (natural water availability) have a tendency to decrease.

\section{CONCLUSION}

In the Kursk Region at the turn of the $20^{\text {th }}-21^{\text {st }}$ centuries climate warmness has been observed. Average annual values of temperature regime are greatly higher than those of 
many years. Firstly, it is connected with stable growth of temperature due to winter months. Definite tendency in humidity has not been revealed. Growth of humidity is due to growth of heavy rains. Negative aftermaths of climate change may affect increase of repetition of dangerous hydrothermal events. Tendency in change of the main parameters of climate in the second half of the $20^{\text {th }}$ century has been kept in the beginning of the new century.

\section{REFERENCES}

[1] Kursk climate. Edited by Doctor of Geography N.P. Tsykalo. L.: Gidrometioizdat, 1984. 112 p. (in Russian)

[2] Data on dangerous natural hydrometeorological events observed in the territory of the Federal State Budget Institution «Central Black Soil Zone Administration on Hydrometeorology and Environment Monitoring (AHEM)» in 2000-2013. Kursk, 2001-2014. (in Russian)

[3] Lukashova O.P., Lunin V.N. Regional effects caused by global climate changes// Snow covering as a factor of climate changes. Voronezh, 2012. - P.75. (in Russian)

[4] The second estimating report by Rosgidromet on climate changes and their aftermaths at the territory of the Russian Federation. - M.: Rosgidromet, 2014. - 1008 p. (in Russian)

[5] Lukashova O.P. Dynamics of nature and climate changes of the territory as a factor of foreststeppe landscape stability (taking the Kursk Region as an example). The materials of the International scientific conference «LANDSCAPE GEOGRAPHY IN THE $21^{\text {ST }}$ CENTURY». Edited by E.A. Pozachenyuk. Publishing P.296 - 298. (in Russian)

[6] Bogatyreva M.A. Dynamics of appearance of dangerous natural events in the Kursk Region for the last 50 years». Digest book of the $9^{\text {th }}$ international youth school-conference «Meridian»: Methods and means of investigation of nature and society. M.: Institute of Geography, Russian Academy of Science, 2016. - P. 22-24. (in Russian)

[7] Bogatyreva M.A. Appearance of contemporary climate changes in the Kursk Region. Magazine «Central Scientific Newsletter». Volume 1. Number 16. Pushkino: Publishig house RITM, 2016. - P. 37-38. (in Russian)

[8] Smolyaninov V.M., Starodubtsev P.P. Complex soil improvement and land irritation in the Central Black Soil Region: State, conditions for development. Voronezh: Istoki, 2011. 179 p. (in Russia)

[9] Goneev I.A., Lukashova O.P., Bogatyreva M.A. Changes of modern Central Russian Upland landscapes caused by natural factors (through the example the Kursk region). The collection includes the 3d International Scientific-Practical Conference on the Humanities and the Natural Science by SCIEURO in London, 2015 - P. 144-154.

[10] Lebedev M. G., Krymskaya O. V. Ecology of the region. Part 3. Ecological climatology and climatic resources of the Central black earth region. Textbook. Ed. by A. N. Petina. - Belgorod: Publishing house of BelSU, 2008. - 196 p. (in Russian) 